Original Research Paper

\title{
Toxicological Consequences of Di-N-Butyl-Phthalate (DBP) on Health of Nile Tilapia Fingerlings
}

\author{
${ }^{1}$ Ehsan H. Abu Zeid and ${ }^{2}$ Al Shimaa A. Khalil \\ ${ }^{1}$ Department of Forensic Medicine and Toxicology, \\ ${ }^{2}$ Department of Fish Management and Diseases, \\ Faculty of Veterinary Medicine, Zagazig University, Zagazig, Egypt
}

Article history

Received: 11-09-2014

Revised: 25-11-2014

Accepted: 15-12-2014

Corresponding Author:

Al Shimaa A. Khalil

Department of Fish

Management and Diseases,

Faculty of Veterinary

Medicine, Zagazig University,

Zagazig, Egypt

Email: drehsanhashim@yahoo.com
Abstract: Phthalic Acid Esters (PAEs) are mainly used in the plastics industry as adhesives and plasticizers. Di- $n$-Butyl Phthalate (DBP) is one of the important members in the family of PAEs was listed as environmental priority pollutants by the US Environmental Protection Agency. The objective of this study was to evaluate the toxicological consequences in Nile Tilapia Oreochromis niloticus $L$. fingerlings, exposed to $1 / 10$ and $1 / 20 \mathrm{LC}_{50}$ of DBP for 8 weeks, via determination of its effect on growth performance and mortality rate, behavioral changes, DNA damaging potential using comet assay (SCGE) in gills, oxidative stress biomarkers via serum reduced glutathione content (GSH), Superoxide Dismutase enzyme activity (SOD) and Malondialdehyde (MDA) concentration as a marker of lipid peroxidation, determine serum Alanine Aminotransferase (ALT), cortisol, creatinine, urea and IgM. Histological alterations occurred in liver, kidneys and gills. In this study $90 O$. niloticus $L$. fingerlings were used. Mortality was investigated in DBP exposed fishes. There was significant decrease in final body weight, weight gain and body gain percentage, condition factor was decreased in fish which exposed to $1 / 10$ and $1 / 20 \mathrm{LC}_{50} \mathrm{DBP}$. Behavioral changes were observed. Significant increase in tail length, tail DNA \% and TM in DBP exposed groups than the control ones except in 1/20 DBP exposed group the increase in tail length and tail moment was non-significant. Significant reduction in serum GSH content, significant increase in SOD, MDA, ALT, cortisol, creatinine and urea levels in groups of DBP exposed fish compared with control one. In the other hand there was a significant decrease in total serum IgM in DBP exposed groups. There were variable histo-pathological alterations in liver, kidney and gills depending on the dose and duration of DBP exposure. The results indicate that DBP induced oxidative stress and the fish seemed to activate compensatory antioxidant defense to cope with the imposed substance. Considering these results, it can be concluded that there is still a need for simultaneous assessment of toxicological consequences of different phthalate esters on multiple cellular target.

Keywords: PAEs-Di-n-Butyl-Phthalate, O. Niloticus L. Fingerlings, Growth Performance, Oxidative Stress, Comet Assay

\section{Introduction}

A plethora of chemicals enter animal feed, human food and water either as undesirable contaminants or as a part of the components of a diet. Phthalate esters, Phthalic Acid Esters (PAEs), are used as plasticizers to increase the flexibility and durability of various materials and primarily used in manufacturing Polyvinyl Chloride (PVC) polymers and Plastisol (Staples et al., 1997). They are also used in personal care products, paints, adhesives, agricultural adjuvants, food products, building materials, medical devices, detergents and surfactants, children's toys, printing, pharmaceuticals, inks and coatings (Hauser and Calafat, 2005). Though most 
phthalate esters have low acute toxicity, phthalate esters are potentially harmful when exposed to humans that can cause toxic and mutagenic effects (Zeng et al., 2009).

Di-N-Butyl-Phthalate (DBP) is one of the most common phthalates. DBP leaches from many products and has become a common contaminant that is present in the environment (ATSDR, 2001). These chemicals can enter aquatic environment through in correct waste disposal from manufacturing units, accidental spillage from industries, effluents from waste water treatment plants and consumer products. Fresh water in South Africa was reported to contain up to $1 \mathrm{mg} \mathrm{L}^{1}$ of DBP (Fatoki and Noma, 2002).

Fish like other aquatic organisms may be exposed to a great range of pollutants includes PAEs absorbing them from water through gill respiration, ingestion of contaminated food particles and dermal exposure (Streit, 1998). Hence, these pollutants may significantly damage certain physiological and biochemical processes when they enter into the organs of fishes (Banaee and Ahmadi, 2011). So, the effects of these pollutants on fishes are of great concern. PAEs also could induce oxidative stress in aquatic organism, such as abalone (Zhou et al., 2011). Therefore, the health of aquatic organisms is linked to hyper generation of ROS and antioxidant compound. Harmful effects of ROS include lipid peroxidation, DNA damage and cell death (Winston and Di Giulio, 1991).

Nile Tilapia fingerlings were employed as a target replica in our study because it is very sensitive to various pollutants and easy to culture and handle in laboratory. In the previous studies, PAEs induced oxidative responses and the antioxidant enzymes played important roles in the defense strategy against PAEs stress. The objective of this investigation was to study the toxicological and pro-oxidant effects on health of Nile Tilapia fingerlings in response to Di-n-butyl phthalate exposure via determination of its adverse effects on growth performance and mortality, behavior, DNA damaging potential in gills, serum biochemical parameters, oxidative stress biomarkers and histopathological changes in gills, liver and kidneys.

\section{Materials and Methods}

\section{Study Species}

Nile tilapia (Oreochromis niloticus L.) fingerlings $(\mathrm{n}=90)$ were obtained from the AL Abassa fish farm, Sharkia province with average weights were $(9 \pm 0.5$ g). Fishes were randomly divided into experimental aquaria $(80 \mathrm{X} 30 \mathrm{X} 40)$ and acclimated for laboratory conditions for 10 days (10 fish/aquarium). During acclimatization, fish were held in permanently aerated tap water. Water renewal was made twice weekly.

\section{Chemicals}

DBP used in this study was of analytical standard grade (CAS number: 84-74-2) and purchased from Sigma-Aldrich Chemical Corporation (Egypt). All the other chemicals were of analytical grade and obtained from Sigma-Aldrich (Egypt).

\section{Experimental Design}

After acclimatization, Nile tilapia (Oreochromis niloticus $L$.) fingerlings $(\mathrm{n}=90)$ with 10.14-10.4 g mean body weights were randomly divided into three groups each with 30 individuals. Each group with two replicates containing fish at density of 15 fish per aquarium. Group 1 was reared in free tap water and treated as control. Fish belonging to group 2 and 3 were exposed for 8 weeks to $1.18 \mathrm{mg} / \mathrm{L}$ and $0.59 \mathrm{mg} / \mathrm{L}$, respectively of DBP that corresponding to $1 / 10$ and $1 / 20$ of LC50 value. LC50 used in this study was $(11.8 \mathrm{mg} / \mathrm{L})$ according to (Hakim and Ali, 2014). Throughout the experimental period fish were fed daily with commercial food at a rate of $4 \%$ of their body weights. Food was not given for $24 \mathrm{~h}$ prior to experiment and dissection. Aquarium water was completely changed every $48 \mathrm{~h}$ to maintain water quality with the appropriate pesticide amount.

\section{Sampling}

Blood samples of fish from all groups were taken from caudal vein and processed immediately according to (Lied et al., 1975). Sera were separated and immediately frozen at -80 further estimations of biochemical parameters. After the end of the experimental period fish were killed immediately and the tissues (liver, kidneys and gills) were collected and fixed in $10 \%$ buffered neutral formalin solution and then passed to $70 \%$ ethanol, dehydrated through graded ethanol series (70-100\%), cleared in xylene and embedded in paraffin. Five micron thick paraffin sections were cut and stained with Haematoxylene-Eosin (H\&E) and examined under a light microscope (Bancroft and Gamble, 2008).

\section{Comet Assay (SCGE)}

After the end of the experimental period fish were killed immediately and the tissues of gills were immediately taken, washed with phosphate buffer saline then kept at -80 for determination of DNA damage by alkaline comet assay according to Singh et al. (1988).

\section{Oxidative Stress Biomarkers}

Serum samples were used for detection of Superoxide Dismutase (SOD) activity according to the method described by Kakkar et al. (1984), Malondialdehyde (MDA) concentration as a marker of lipid peroxidation according to the method adapted by Ohkawa et al. (1979), reduced glutathione (GSH) content according to the method described by Moron et al. (1979).

\section{Serum Biochemical Parameters}

Serum Alanine Aminotranseferase (ALT) was determined colorimetrically according to method of (Reitman and Frankel, 1957) and modified by (King, 1965), serum urea level according to the method described by (Chaney and Marbach, 1962), serum 
creatinine according to method adapted by (Husdan and Rapoport, 1968), serum cortisol according to the method described by (Foster and Dunn, 1974). Finally, IgM levels were determined according to the method described by (Siwicki and Anderson, 1993). Protein levels estimation were determined by the method of (Lowry et al., 1951) using bovine serum albumin as standard.

\section{Statistical Analysis}

Statistical analysis was based on comparing the values between the untreated control group with the low and high acute FNT exposed groups. The results are expressed as means $\pm \mathrm{SE}$. The statistical significance of the data has been determined using one way Analysis of Variance (ANOVA-LSD) using the Statistical Package for Social Science (SPSS, 1997). The level of significance was taken as $(\mathrm{p}<0.05)$.

\section{Results}

\section{Effect of DBP Intoxication on Growth Performance of Nile Tilapia O. Niloticus Fingerlings}

In the existing study, the results demonstrated in Table 1 showed that significant decrease in final body weight, weight gain and body gain percentage. Condition factor was decreased in fish after chronic exposure to $1 / 10$ and $1 / 20 \mathrm{LC}_{50}$ exposure levels of DBP compared with control ones.

\section{Effect of DBP on Behavioral Response and Mortality of $O$. Niloticus Fingerlings}

The results showed in Table 2 demonstrate that, the mortality rate to fish exposed to $1 / 10$ and $1 / 2096 \mathrm{hrs} \mathrm{LC}_{50}$ of DBP were 36.6 and $26.6 \%$ respectively. The previous fish appeared sluggish and not respond to tested reflexes, dark coloration, presence of thick mucus was present and severe congestion in internal organs was recorded.

\section{Evaluation of DNA Damage Via Comet Assay}

In the existent study, intoxication of DBP in Nile tilapia fingerlings resulted in DNA damage as indicated by the significant increase in tail length (px), tail DNA\% and TM in groups of DBP intoxicated fish compared with the control ones in these experimental circumstances as presented in Table 3 and Fig. 1. Only, group exposed to $1 / 20 \mathrm{DBP}$ intoxication showed nonsignificant increase in tail length and tail moment than the control group at $\mathrm{p}<0.05$.

\section{Oxidative Stress Biomarkers}

Relating to the effect of chronic low and high sub lethal intoxication of Nile tilapia fingerlings to DBP on oxidative stress parameters, the data demonstrated in Table 4 declared a significant depletion of serum reduced glutathione content (GSH), significant elevation in the serum SOD activity and in lipid peroxidation bimarker (MDA) after DBP exposure versus control group at $\mathrm{p}<0.05$.

\section{Serum Biochemical Parameters}

The results demonstrated in Table 5 revealed that, the fish exposed to $1 / 10$ and $1 / 20 \mathrm{LC}_{50}$ of DBP showed significant increase in the level of ALT, creatinine, urea and cortisol in comparing with control group. The fish exposed to $1 / 10$ and $1 / 20 \mathrm{LC}_{50}$ of DBP showed significant decrease in Igm level in comparing with control group.

\section{Histopathological Finding}

No microscopic abnormalities were seen in the liver, kidneys and gills of control group. In sub-chronic exposure to $1 / 20$ and $1 / 10 \mathrm{LC}_{50}$ of DBP, liver showed moderate vacuolations in the hepatocytes and hydropic degeneration with pyknotic nuclei. Sometimes, the portal areas showed necrosis in the pancreatic acini and few lymphocytes infiltrations (Fig. 2.4). Congestion of hepatic blood vessels and hemorrhage were detected.

Table 1. Effect of DBP concentration $\left(1_{/ 10}\right.$ and $\left.1_{/ 20} \mathrm{LC}_{50}\right)$ on growth performance on $O$. niloticus fingerlings

\begin{tabular}{llll}
\hline Group parameters & Control & $1_{/ 10} \mathrm{LC}_{50}$ & $1_{/ 20} \mathrm{LC}_{50}$ \\
\hline Initial body weight $(\mathrm{g})$ & $10.14 \pm 0.49^{\mathrm{a}}$ & $10.2 \pm 0.24^{\mathrm{a}}$ & $10.33 \pm 0.23^{\mathrm{a}}$ \\
Initial total body length $(\mathrm{cm})$ & $8.5 \pm 0.7^{\mathrm{a}}$ & $8.5 \pm 0.41^{\mathrm{a}}$ & $8.5 \pm 0.2^{\mathrm{a}}$ \\
"Final body weight $(\mathrm{g})$ & $33.41 \pm 1.4^{\mathrm{a}}$ & $21.5 \pm 0.35^{\mathrm{b}}$ & $23.4 \pm 0.45^{\mathrm{b}}$ \\
${ }^{*}$ "Final total body length $(\mathrm{cm})$ & $12.3 \pm 0.4^{\mathrm{a}}$ & $12 \pm 0.5^{\mathrm{a}}$ & $12.1 \pm 0.42^{\mathrm{a}}$ \\
Weight gain $(\mathrm{gm})$ & $23.58 \pm 0.31^{\mathrm{a}}$ & $11.23 \pm 0.25^{\mathrm{b}}$ & $13.05 \pm 0.22^{\mathrm{b}}$ \\
Body gain \% & 229 & 110 & 126 \\
Condition factor & & & \\
a. at start & 1.65 & 1.79 & -14 \\
b. at end & 1.66 & 1.24 & -32 \\
Percent of change condition & 1.68 & & -36 \\
factor $\%$ of initial value) & & &
\end{tabular}

factor ( $\%$ of initial value)

Means within the same row bearing different subscripts are significant at $\mathrm{p} \leq 0.05$

${ }^{*}$ Final body weight after 8 week

${ }^{*}$ *Final total body length after 8 week 


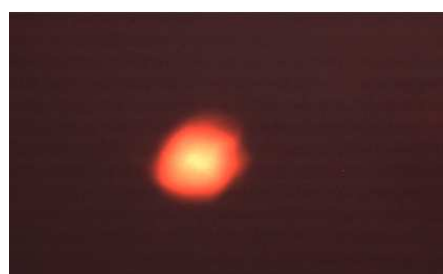

(A)

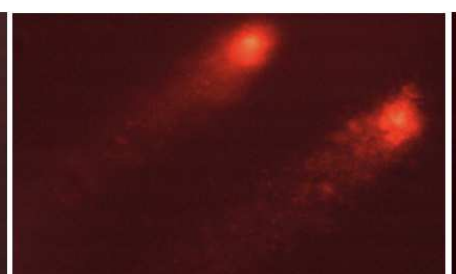

(B)

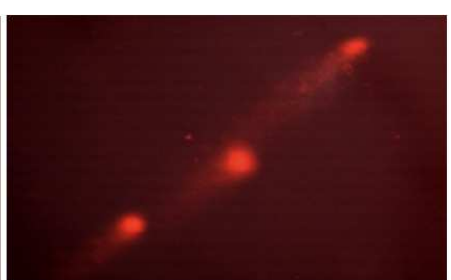

(C)

Fig.1. Nucleus of gill cells of Nile tilapia fingerlings after sub-chronic exposure to $1 / 10$ and $1 / 20$ DBP sub lethal concentrations (A) control group almost normal condensed type nucleus (B) 1/10 DBP exposed group showed coma shaped nucleus (C) 1/20 DBP exposed group showed coma shaped nucleus
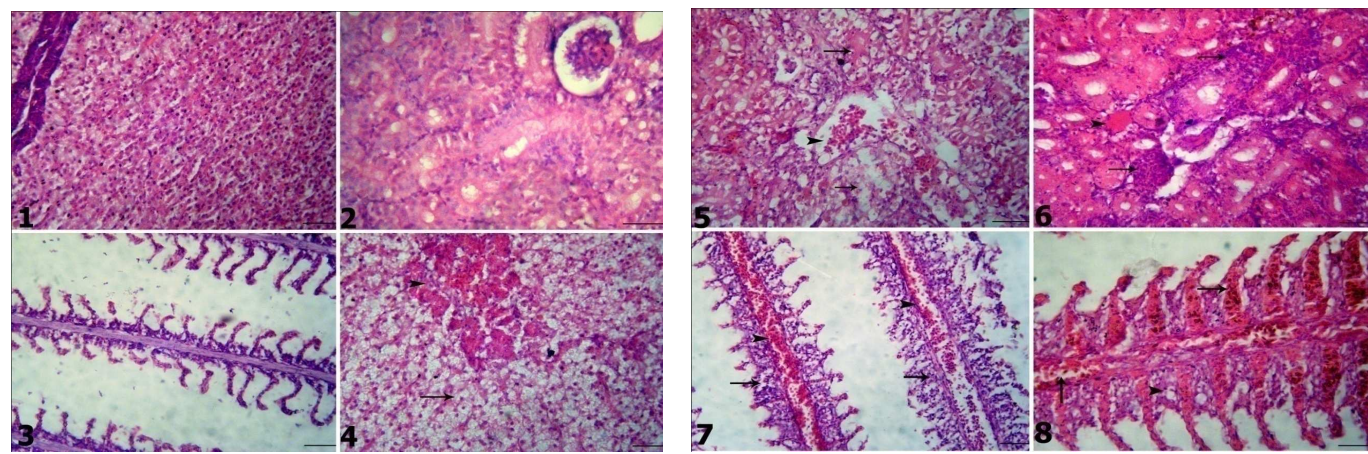

Fig. 2. Photomicrographs showing control liver (1). Control kidney (2). Control gill (3). Chronic exposure to DBP (4) Liver shows moderate vacuolations in the hepatocytes and hydropic degeneration besides necrosis in the pancreatic acini and few lymphocytes infiltrations. (5) Kidney shows congestion and hemorrhage with focal vacuolations in the renal tubular epithelia. (6) Kidney shows coagulative necrosis and few interstitial round cells aggregations. (7 and 8) Gill shows congestion of lamellar blood capillaries and hemorrhage besides focal epithelial proliferations, increased goblet cells and fusion at the base of gill filaments. HE $(\mathrm{Bar}=100 \mu \mathrm{m})$

Table 2. Effect of DBP concentration $\left(1_{10}\right.$ and $\left.1_{/ 20} \mathrm{LC}_{50}\right)$ on behavioral response and mortality rate in $O$. niloticus fingerlings Observation (week)

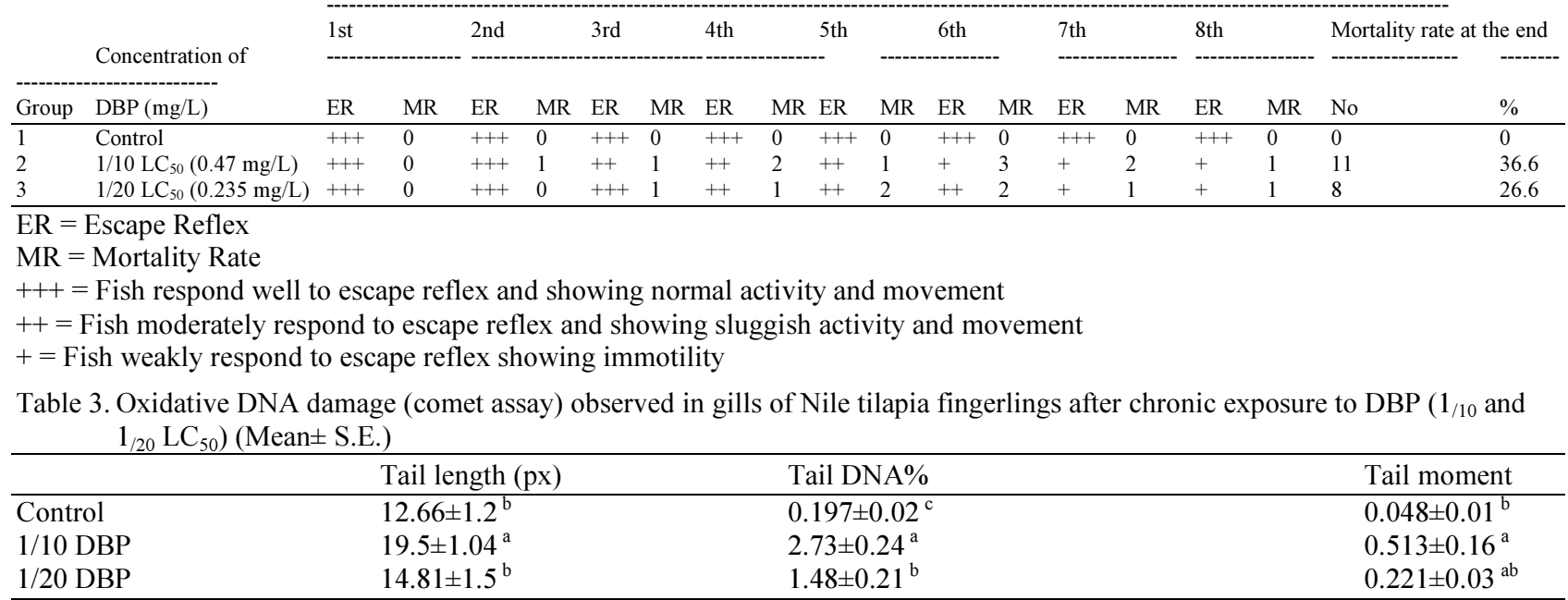

Means in the same column having the different superscript letter were significantly different $(p<0.05)$

Table 4. Changes in serum GSH content (ng/mL), SOD activity (unit/ $\mathrm{mg}$ protein) and MDA (nmol/mL) concentration of Nile tilapia fingerlings after exposure to DBP $\left(1_{/ 10}\right.$ and $\left.1_{/ 20} \mathrm{LC}_{50}\right)($ Mean \pm S.E. $)$

\begin{tabular}{llll}
\hline & GSH $(\mathrm{ng} / \mathrm{mL})$ & SOD $($ unit/L) & MDA (nmol/L) \\
\hline Control & $9.91 \pm 0.3^{\mathrm{a}}$ & $30.03 \pm 1.2^{\mathrm{c}}$ & $48.97 \pm 0.76^{\mathrm{c}}$ \\
$1 / 10 \mathrm{DBP}$ & $3.12 \pm 0.3^{\mathrm{c}}$ & $51.7 \pm 1.3^{\mathrm{a}}$ & $88.55 \pm 2.57^{\mathrm{a}}$ \\
$1 / 20 \mathrm{DBP}$ & $5.95 \pm 0.6^{\mathrm{b}}$ & $35.7 \pm 0.49^{\mathrm{b}}$ & $57.28 \pm 1.03^{\mathrm{b}}$ \\
\hline
\end{tabular}

Means in the same column having the different superscript letter were significantly different at $(\mathrm{p}<0.05)$ 
Table 5. Changes in serum biochemical parameters of Nile tilapia fingerlings after chronic exposure to DBP $\left(1_{/ 10}\right.$ and $1_{/ 20}$ LC 50 (Mean \pm S.E.)

\begin{tabular}{llllll}
\hline Parameter group & AlT $(\mathrm{IU} / \mathrm{dL})$ & Cortisol $(\mathrm{mg} / \mathrm{dL})$ & Creatinine $(\mathrm{mg} / \mathrm{dL})$ & Urea $(\mathrm{IU} / \mathrm{dL})$ & IgM value $(\mu \mathrm{g} / \mathrm{mL})$ \\
\hline Control & $17.67 \pm 0.33^{\mathrm{c}}$ & $6.14 \pm 0.005^{\mathrm{c}}$ & $0.15 \pm 0.005^{\mathrm{c}}$ & $7.67 \pm 0.33^{\mathrm{c}}$ & $23.38 \pm 0.33^{\mathrm{a}}$ \\
$1 / 10$ DBP & $30.67 \pm 0.67^{\mathrm{a}}$ & $16.05 \pm 0.53^{\mathrm{a}}$ & $1.0 \pm 0.03^{\mathrm{a}}$ & $19.00 \pm 0.57^{\mathrm{a}}$ & $9.33 \pm 0.08^{\mathrm{b}}$ \\
$1 / 20$ DBP & $27.00 \pm 0.57^{\mathrm{b}}$ & $13.05 \pm 0.35^{\mathrm{b}}$ & $0.84 \pm 0.02^{\mathrm{b}}$ & $17.33 \pm 0.33^{\mathrm{b}}$ & $11.38 \pm 0.11^{\mathrm{c}}$ \\
\hline
\end{tabular}

Means in the same column having the different superscript letter were significantly different at $(\mathrm{p}<0.05)$

Slight intravascular hemolysis was rarely seen. The kidneys showed congestion, edema and hemorrhage. Cloudy swelling and focal vacuolations in the renal tubular epithelia were observed (Fig. 2.5). Interstitial aggregations of round cells were noticed. Hyaline and cellular casts were seen inside the lumina of some renal tubules (Fig. 2.6). The gills revealed congestion of lamellar blood capillaries and hemorrhage. Focal epithelial proliferations with increased goblet cells and fusion at the base of gill filaments were visualized besides few leukocytic infiltrations (Fig. 2.7. and 2.8.). Therefore mentioned lesions were prominent and slightly increased with $1 / 10 \mathrm{LC}_{50}$ of DBP.

\section{Discussion}

Concerning the estimation of DBP $96 \mathrm{~h} \mathrm{LC}_{50}$ value in Nile tilapia fingerlings, the results of existing study showed that DBP $96 \mathrm{~h} \mathrm{LC}_{50}$ in Nile tilapia fingerlings is about $12.4 \mathrm{mg} \mathrm{L}{ }^{1}$. This estimate indicates that DBP is moderately toxic to Nile tilapia. It is difficult to assess the toxicity of DBP to Nile tilapia fingerlings from the limited data available. Results of present study are in dissimilarity with (Mayer Jr. and Sanders, 1973) who mentioned that acute $96 \mathrm{hr}$ bioassays indicate that the toxicity of DBP to fish is relatively low. This may be attributed to species differences, or may be ascribed to individual, seasonal and environmental variations or may be qualified to differences in the development stage and size of fish used.

Esters of phthalic acid including DBP are chemical agents used to improve the plasticity of industrial polymers. Their ubiquitous use in multiple commercial products results in extensive exposure to humans and the environment. However, the toxic effects of DBP on the health of Nile tilapia still persistent unclear.

The previously estimated value of DBP $96 \mathrm{~h} \mathrm{LC}_{50}$ in Nile tilapia fingerlings showed that DBP $96 \mathrm{~h} \mathrm{LC}_{50}$ is about $11.8 \mathrm{mg} / \mathrm{L}$ (Hakim and Ali, 2014). This estimate indicates that DBP is moderately toxic to Nile tilapia. But, it is difficult to assess the toxicity of DBP to Nile tilapia fingerlings from the limited data available. The results of the (Mayer Jr. and Sanders, 1973) who mentioned that acute 96 hour bioassays indicate that the toxicity of DBP to fish is relatively low. This may be attributed to species differences, or may be ascribed to individual, seasonal and environmental variations or may be qualified to differences in the development stage and size of fish used.

So the aim of the present study is to assess the detrimental consequences after DBP sub-chronic exposure in Nile Tilapia fingerlings. As regards to effects of DBP on growth performance the present study showed that sub-chronic exposure to $1 / 10$ and $1 / 20 \mathrm{LC}_{50}$ of DBP resulted in significant decrease in final body weight, weight gain, body gain percentage and condition factor. These results are similar to that obtained by (Liu et al., 2012) reported a significant decrease in body weight of male rats after prenatal exposure to DBP. These results are in difference with that obtained by (Xu et al., 2014). This difference may be attributed to species differences, different inborn capacity of each species to detoxify pollutants and different tolerance to DBP, or may be ascribed to individual, seasonal and environmental variations or may be qualified to differences in the development stage and size of fish used.

Regarding to effect of DBP on behavior, the current study showed that DBP exposed fishes showed behavioral changes and did not respond to tested reflexes. One explanation for this behavior is that DBP may act as a stress that results in behavioral changes, general stress behavior, as a mechanism by which animals adapt to changes in their environment, including exposure to contaminants as mentioned by (Kane et al., 2005). Stress responses caused by pollution can result from physiological compensatory mechanisms that compensate for toxic effects of the pollutant (Beyers et al., 1999).

Regarding oxidative DNA damage, comet assay is the most widely used as a non chromatographic method for assessment of oxidative DNA damage (Gedik and Collins, 2005). So we select the test for studying genotoxicity of DBP than other genotoxicity assays (e.g., micronuclei, mutations, structural chromosomal aberrations). Recent in vitro studies using the alkaline comet assay (single-cell gel electrophoresis) found Di- $n$ Butyl Phthalate (DBP) to be genotoxic in human epithelial cells of the upper aero-digestive tract (Kleinsasser et al., 2000a), as well as in mucosal cells and lymphocytes (Kleinsasser et al., 2000b).

In this study Nile tilapia fingerlings showed positive genotoxic effect of DBP using SCGE assay. These results are in concordance with that obtained by (Duty et al., 2003). Depletion of GSH content in DBP exposed fishes (obtained in this study) below a critical level prevents the conjugation of xenobiotics (DBP) to GSH for detoxification and enables them to freely combine covalently with DNA, RNA, or cell proteins resulting in cellular damage (Meister and Anderson, 1993). Also, Reduction of GSH by xenobiotics (DBP) below a certain 
level allows the enhancement of lipid peroxidation and induction of ROS, which could also cause formation of DNA single strand breaks (Banu et al., 2001).

The antioxidant defense and immune response in fish are the important defense against insult by environmental contaminants. As oxidative stress is the first response to environment stressors (Livingstone, 2001), we think that Nile tilapia fingerlings initiates antioxidant and detoxification responses to counteract a DBP exposure. In the present study, we found that DBP exposure resulted in generating of oxidative stress in Niletilapia fingerlings indicated by increased level of SOD, MDA and depletion of GSH content. These results are in accordance with that obtained by (Zhou et al., 2011; Xu et al., 2013). The release of ROS is one of essential reasons for the generation of oxidative stress and the depletion of antioxidant defense. It is well known that the production of ROS in biological system in response to contamination is associated with cell injury or death, lipid peroxidation and membrane damage. Once the free radicals are formed, tissue cells will protect themselves by inducing scavenging enzymes such as Superoxide Dismutase (SOD). SOD converts the free radicals into Hydrogen Peroxide $\left(\mathrm{H}_{2} \mathrm{O}_{2}\right)$ and molecular Oxygen $\left(\mathrm{O}_{2}\right)$ to reduce the toxicity of free radicals in the tissue cell. Our results showed that SOD was increased and decrease in GSH levels in the DBPtreated groups. These results indicated that DBP seems to induce free radicals in fish. Responding to the stress of increased free radical, the treated fish would induce scavenging enzymes (SOD) and depletion of antioxidant molecules (GSH) to reduce the damage of the free radicals as a detoxification mechanism. Increased MDA concentration in DBP exposed fish may be attributed to the imbalance between ROS generation and removal results in damage to DNA, lipids and proteins (Valko et al., 2006). Lipid peroxidation of polyunsaturated fatty acids is initiated due to the formation of ROS. MDA is among secondary products of lipid peroxidation and is extensively studied as a potential indicator of oxidative imbalance during the onset of many diseases (Niki, 2008). These results also indicated that DBP resulted in an increase of ROS.

On the focus of DBP effect on serum biochemical parameters, obtained results in current study investigated that $1 / 10$ and $1 / 20 \mathrm{DBP}$ significantly altered compared with control groups. These results are in disagreement with that obtained by (Zhong et al., 2013) who observed non significant changes in DBP treated rats than control ones. This may be attributed to difference in study species. Generally elevated ALT enzyme level may indicate degenerative changes and hypofunction of liver as the toxicants effects on the hepatocytes are in the form of tissue damage in which cellular enzymes are released from the cells into the blood serum which gives an indication of the hepatotoxic effect of toxicants (Firat et al., 2011). The above findings were confirmed by the obtained histopathological changes in liver and kidney under the intoxication effect of DBP in the present study. Phthalates such as DBP DEHP and DINP altered liver and kidney function causing a variety of alterations in kidney function in animals including renal cysts, reduction in creatinine clearance and transitional cell carcinoma (Woodward, 1990).

Concerning to cortisol level, the obtained data in the existent investigate showed significant increase in the serum cortisol level. Cortisol assessment generally has been used as a sign of stress response in fish (Wendelaar Bonga, 1997). The stress hormone cortisol has been shown to increase glucose production in fish, by both gluconeogenesis and glycogenolysis and likely play an important role in the stress-associated increase in plasma glucose concentration (Iwama et al., 1999). In regards to the increase in urea and creatinine may be due the decrease of glomerular infiltration rate of kidney and tubular dysfunction (Saleh et al., 2007) which is confirmed by the obtained significant histopathological injury in kidneys of Nile tilapia after DBP exposure. Due to its complexity, immune system is exceptionally sensitive to environmental contaminants and there is evidence that xenobiotics including PAEs can impact cell immune response in aquatic organisms (Chen and Sung, 2005). Alternation of immune function is used in assessing ecotoxicological effects of contaminant exposure (Zelikoff et al., 2002). The histopathological changes in liver, kidneys and gills in present study may be attributed to the generation of oxidative stress and consequent lipid peroxidation occurred by DBP obtained in the current study and reported in many species. Two broad outcomes of lipid peroxidation are structural damage of cellular membranes and generation of oxidized products. These reactive products are thought to be the major cause of tissue damage

\section{Conclusion}

The present study demonstrated that DBP induced oxidative stress, immune responses and oxidative DNA damage in Nile tilapia fingerlings. Thus, it has been concluded that the tested oxidative stress biomarkers should be useful as indicators for the risk assessment of DBP in the aquatic environment and there is still a need for further assessment of toxicological consequences of different phthalate esters on multiple cellular targets.

\section{Author's Contributions}

All authors equally contributed in this work.

\section{Ethics}

This article is original and contains unpublished material. The corresponding author confirms that all of 
the other authors have read and approved the manuscript and no ethical issues involved.

\section{References}

ATSDR, 2001. Agency for toxic substances and disease registry. Toxicological Profile for Di-n-butyl Phthalate (ATSDR). Atlanta, GA, USA.

Banaee, M. and K. Ahmadi, 2011. Sub-lethal toxicity impacts of endosulfan on some biochemical parameters of the freshwater crayfish (Astacus leptodactylus). Res. J. Environ. Sci., 5: 827-835.

Bancroft, J.D. and M. Gamble, 2008. Theory and Practice of Histological Techniques. 5th Edn., Churchill Livingstone. New York, London, Philadelphia.

Banu, B.S., K. Danadevi, M.F. Rahman, Y.R. Ahuja and J. Kaiser, 2001. Genotoxic effect of monocrotophos to sentinel species using comet assay. Food Chemical Toxicol., 39: 361-366. DOI: $10.1016 / \mathrm{S} 0278-6915(00) 00141-1$

Beyers, D.W., Rice, J.A., W.H. Clements and C.J. Henry, 1999. Estimating physiological cost of chemical exposure: Integrating energetics and stress to quantify toxic effects in fish. Can. J. Fish. Aquat. Sci., 56: 814-822. DOI: 10.1139/f99-006

Chaney, A.L. and E.P. Marbach, 1962. modified reagents for determination of urea and Ammonia. Clin. Chem., 8: 130-132. PMID: 13878063

Chen, W.L. and H.H. Sung, 2005. The toxic effect of phthalate esters on immune responses of giant freshwater prawn (Macrobrachium rosenbergii) via oral treatment. Aquat. Toxicol., 74: 160-171. DOI: 10.1016/j.aquatox.2005.05.008

Duty, S.M., N.P. Singh, M.J. Silva, D.B. Barr and J.W. Brock et al., 2003. The relationship between environmental exposures to phthalates and DNA damage in human sperm using the neutral comet assay. Environ. Health Perspectives, 111: 1164-1169. PMID: 12842768

Fatoki, O.S. and A. Noma, 2002. Solid phase extraction method for selective determination of phthalate esters in the aquatic environment. Water, Air Soil Pollution, 40: 85-98. DOI: $10.1023 / \mathrm{A}: 1020134707450$

Firat, O., H.Y. Cogun, T.A. Yüzereroğlu, G. Gök and O. Firat et al., 2011. A comparative study on the effects of a pesticide (cypermethrin) and two metals (copper, lead) to serum biochemistry of Nile tilapia, Oreochromis niloticus. Fish Physiol. Biochem., 37: 657-666. DOI: 10.1007/s10695-011-9466-3

Foster, L.B. and R.T. Dunn, 1974. Single-antibody technique for radioimmunoassay of cortisol in unextracted serum or plasma. Clin. Chem., 20: $365-368$.

Gedik, C.M. and S.A. Collin, 2005. Establishing background level of base oxidation in human lymphocyte DNA: Results of inter laboratory validation study. FASEB J., 19: 82-84.
Hakim, Y. and H.A. Ali, 2014. Evaluation of the toxic effects of phtalate, Di-n-Butule Phthalate (DBP) on health of Oreochromis niloticus. World J. Fish Marine Sci.

Husdan, H. and A. Rapoport, 1968. Estimation of creatinine by the Jaffe reaction. A comparison of three methods. Clin. Chem., 14: 222-238. PMID: 5637963

Hauser, R. and A.M. Calafat, 2005. Phthalates and human health. Occup. Environ. Med., 62: 806-818. DOI: 10.1136/oem.2004.017590

Iwama, G.K., M.M. Vijayan, R.B. Forsyth and P.A. Ackerman, 1999. Heat shock proteins and physiological in fish. Am. Zool., 39: 901-909.

Kakkar, P., B. Das and P.N. Viswanathan, 1984. A modified spectrophotometric assay of superoxide dismutase. Indian J. Biochem. Biophys., 21: 130-132

Kane, A.S., J.D. Salierno and S.K. Brewer, 2005. Fish Models in Behavioral Toxicology: Automated Techniques, Updates and Perspectives. In: Methods in, Aquatic Toxicology, Ostrander, G.K. (Ed.), CRP Press, pp: 559-590.

King, J., 1965. Practical Clinical Enzymology. 1st Edn., Van Nostrand Co. Ltd., London, pp: 363.

Kleinsasser, N.H., E.R. Kastenbauer, H. Weissacher, R.K. Muenzenrieder and U.A. Harréus, 2000a. Phthalates demonstrate genotoxicity on human mucosa of the upper aerodigestive tract. Environ. Mol. Mutagen., 35: 9-12. DOI: 10.1002/(SICI)10982280(2000)35:1<9::AID-EM2>3.0.CO;2-1

Kleinsasser, N.H., H. Weissacher, E.R. Kastenbauer, P. Dirschedl and B.C. Wallner et al., 2000b. Altered genotoxicity in mucosal cells of head and neck cancer patients due to environmental pollutants. Eur. Arch Otorhinolaryngol., 257: 337-342.

DOI: $10.1007 / \mathrm{s} 004059900220$

Lied, E., J. Gjerde and O.R. Braekkan, 1975. Simple and rapid technique for repeated blood sampling in rainbow trout. J. Fish. Res. Board Canada, 32: 699-701. DOI: 10.1139/f75-089

Liu, S.B., Z. Ma, W.L. Sun, X.W. Sun and Y. Hong et al., 2012. The role of androgen-induced growth factor (FGF8) on genital tubercle development in a hypospadiac male rat model of prenatal exposure to di-n-butyl phthalate. Toxicology, 293: 53-58.

DOI: $10.1016 /$ j.tox.2011.12.010

Livingstone, D.R., 2001. Contaminant-stimulated reactive oxygen species production and oxidative damage in aquatic organisms. Marine Pollution Bull., 42: 656-666. DOI: $10.1016 / \mathrm{S} 0025-326 \mathrm{X}(01) 00060-1$

Lowry, O.H., N.J. Rosenbrough, A.L. Farr and R.J. Randall, 1951. Protein measurement with folin phenol reagent. Biol. Chem., 193: 265-275.

Mayer Jr. F.L. and H.O. Sanders, 1973. Toxicology of phthalic acid esters in aquatic organisms. Environ. Health Perspect., 3: 153-157. 
Meister, A. and M.E. Anderson, 1993. Glutathione. Ann. Rev. Biochem., 32: 711-760.

Moron, M.S., J.W. Depierre and B. Mannervik, 1979. Levels of glutathione, glutathione reductase and glutathione S-transferase activities in rat lung and liver. Biochim. Biophys. Acta., 582: 67-78. DOI: $10.1016 / 0304-4165(79) 90289-7$

Niki, E., 2008. Lipid peroxidation products as oxidative stress biomarkers. Biofactors, 34: 171-180. DOI: $10.1002 /$ biof.5520340208

Ohkawa, H., N. Ohishi and K. Yagi, 1979. Assay for lipid peroxidation in animal tissues by thiobarbituric acid reaction. Ann. Biochem., 95: 351-358. DOI: 10.1016/0003-2697(79)90738-3

Reitman, S. and S. Frankel, 1957. A colorimetric method for the determination of glutamic oxaloacetic and glutamic pyruvic transaminases. Am. J. Clin. Pathol., 28: 56-63. PMID: 13458125

Saleh, G.A., G. El-Nobi and N.S. Ahmed Abd EL-Bary, 2007. Study on the effect of Reldan (Chlorpyrifosmethyl) on health and growth of Nile tilapia (Oreochromis niloticus) fingerlings. Zag. Vet. J., 35: 110-121.

Singh, N.P., M.T. McCoy, R.R. Tice and E.L. Schneider, 1988. A simple technique for quantitation of low levels of DNA damage in individual cells. Exp. Cell Res., 175: 184-191. DOI: $10.1016 / 0014-4827(88) 90265-0$

Siwicki, A.K., D.P. Anderson and J. Waluga, 1993. Nonspecific defense mechanisms assay in fish. II. Potential killing activity of neutrophils and macrophages, lysozyme activity in serum and organs and total immunoglobulin level in serum. Fish Disease Diagnosis and Prevention Methods, Olzsztyn, Poland, pp: 105-112.

SPSS, 1997. Statistical package for social sciences. SPSS Inc., USA.

Streit, B., 1998. Bioaccumulation of contaminants in fish. Fish Ecotoxicol., 86: 353-387. DOI: $10.1007 / 978-3-0348-8853-012$

Staples, C.A., D.R. Peterson, T.F. Parkerton and W.J. Adams, 1997. The environmental fate of phthalate esters: A literature review. Chemosphere, 35: 667-749. DOI: 10.1016/S0045-6535(97)00195-1

Valko, M., C.J. Rhodes, J. Moncol, M. Izakovic and M. Mazur, 2006. Free radicals, metals and antioxidants in oxidative stress-induced cancer. Chem. Biol. Interact., 160: 1-40. DOI: 10.1016/j.cbi.2005.12.009
Wendelaar Bonga, S.E., 1997. The stress response in fish. Physiol. Rev., 7: 591-625.

Winston, G.W. and R.T. Di Giulio, 1991. Prooxidant and antioxidant mechanisms in aquatic organisms. Aquatic Toxicol., 19: 137-161. DOI: 10.1016/0166-445X(91)90033-6

Woodward, KN., 1990. Phthalate esters, cystic kidney disease in mammals and possible effects on human health: A review. Hum. Exp. Toxico1., 9: 397-401. DOI: $10.1177 / 096032719000900607$

Xu, H., X. Shao, Z. Zhang, Y. Zou and X. Wu et al., 2013. Oxidative stress and immune related gene expression following exposure to di-n-butyl phthalate and diethyl phthalate in zebrafish embryos. Ecotoxicol. Environ. Safety, 93: 39-44. DOI: 10.1016/j.ecoenv.2013.03.038

Xu, N., P. Chen, L. Liu, Y. Zeng and H. Zhou et al., 2014. Effects of combined exposure to $17 \alpha$ ethynylestradiol and dibutyl phthalate on the growth and reproduction of adult male zebrafish (Danio rerio). Ecotoxicol. Environ. Saf., 107: 61-70.

DOI: $10.1016 /$ j.ecoenv.2014.05.001

Zelikoff, J.T., E. Carlson, Y. Li, A. Raymond and J. Duffy et al., 2002. Immunotoxicity biomarkers in fish: Development, validation and application for field studies and risk assessment. Hum. Ecol. Risk Assess., 8: 253-263. DOI: $10.1080 / 20028091056890$

Zeng, F., K. Cui, Z. Xie, L. Wu and D. Luo et al., 2009. Distribution of phthalate_esters in urban soils of subtropical city, Guangzhou, China. J. Hazard Mater., 164: 1171-1178.

DOI: $10.1016 /$ j.jhazmat.2008.09.029

Zhong, Z.W., Y. Ling, J.X. Dong, L. Ning and F.Y. Xiang, 2013. Combined subchronic toxicity of bisphenol a and dibutyl phthalate on male rats. Biomed. Environ. Sci., 26: 63-69. DOI: 10.3967/0895-3988.2013.01.008

Zhou, J., Z.H. Cai and K.Z. Xing, 2011. Potential mechanisms of phthalate ester embryotoxicity in the abalone Haliotis diversicolor supertexta. Environ. Pollution, 159: 1114-1122.

DOI: $10.1016 / \mathrm{j}$. envpol.2011.02.016 